\title{
A new genus of Devonian Ostracoda
}

\author{
ALEKSANDR N. ORLOV \\ All-Russia Petroleum Scientific-Research, Geological-Exploration Institute (VNIGRI), Liteiny, 39, St.-Petersburg, 191104, \\ Russia.
}

\begin{abstract}
Baritella, a new genus of Ostracoda, is described from the Devonian rocks of Timan-Pechora province, Russia. This genus belongs to the superorder Podocopamorphes Kozur, 1972, but its systematic position is not clear. Three new species belong in Baritella: B. thatchevae, $B$. dmitrievae and $B$. pavlouskajae. All these species were found in shallow-water deposits of the open sea. J. Micropaiaeontol. 16(1): 59-64, May 1997.
\end{abstract}

\section{INTRODUCTION}

Devonian ostracods from Timan-Pechora province (Fig. 1) show high diversity. The new genus belongs to the superorder Podocopamorphes Kozur, 1972, but its systematic position is not clear. The stratigraphic range of Baritella gen. nov. is limited to Timan and Sargaev regional substages. These correlate with the Pa. transitans and $M$. falsiovalis conodont zones (Fig. 2). The geographical occurrence of this genus is restricted to the Timan-Pechora province. All three species were found in shallow-water deposits of the open sea. The ostracod-bearing strata have abundant assemblages of shallow-water fossils in each case. The accompanying fauna comprises: brachiopods, tentaculites, fish, conodonts, crinoids and a rich association of ostracods (Judina \& Moskalenko, 1988; Orlov, 1990).

The adductorial pit or scar on the carapace surface is absent but it is visible on translucent carapaces of Baritella dmitrievae sp. nov. and B. pavlovskajae sp. nov. (Figs $3 \mathrm{~A}, \mathrm{C})$. The carapace of $B$. tkatchevae sp. nov. has a depression, the lower part of which is situated where $B$. dmitrievae sp. nov. and B. pavlovskajae sp. nov. have an adductorial scar (Fig. 3E). Therefore, this is interpreted as an adductorial depression. Considerable overlap of valves is seen on the central margin of the translucent carapaces of all species (Figs 3B,D,F).

\section{SYSTEMATIC DESCRIPTIONS \\ Superorder Podocopamorphes Kozur, 1972 Incertae sedis \\ Genus Baritella gen. nov.}

Type species. Baritella tkatchevae sp. nov.

Derivation of name. Free combination of letters.

Diagnosis. Carapace subrectangular or subtrapezoidal, elongated in lateral outline. Dorsal margin straight and long. Ventral margin slightly convex. Maximum length in middle or lower part of carapace. Maximum height in anterior, middle or posterior part of carapace. Maximum width in middle or posterior part. Adductorial depression may be present or absent. Postero-ventral part of the right valve has a postero-ventral spine. The spine may be

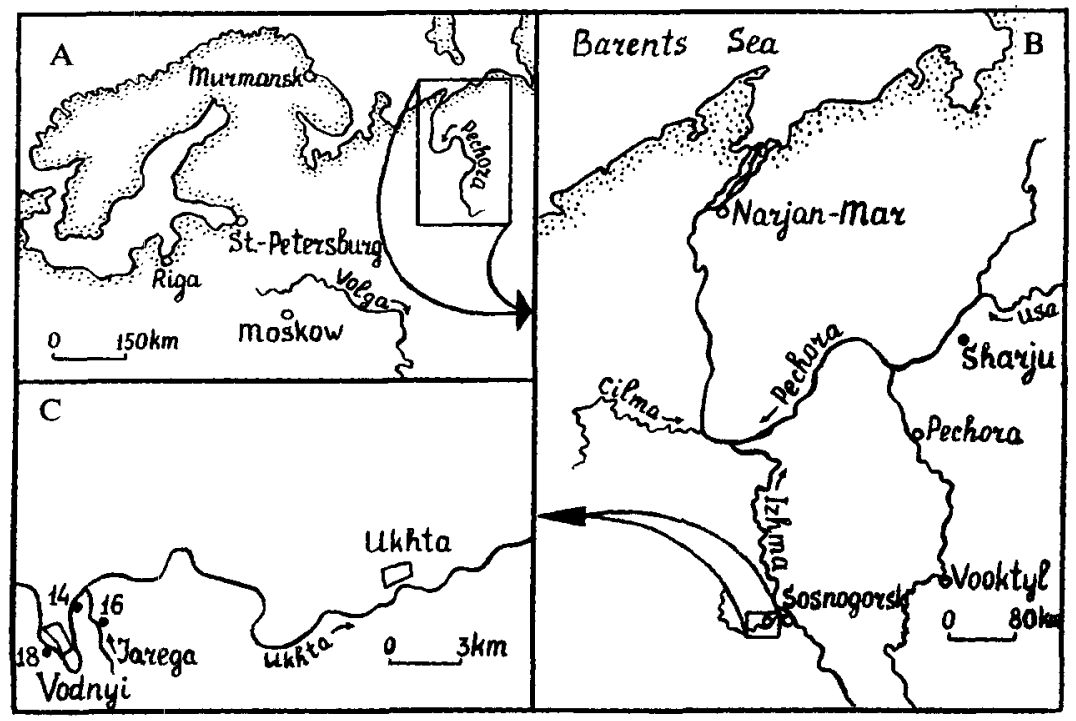

Fig. 1. (A) Map of the northeastern part of Europe. (B) Map of Timan-Pechora province with the position of the exposure on the Sharju River. (C) Map of part of the Ukhta region with exposures 14,16 and 18. 


\begin{tabular}{|c|c|c|c|c|c|}
\hline Stages & $\begin{array}{l}\text { Standard } \\
\text { Conodont } \\
\text { Zonation }\end{array}$ & $\begin{array}{l}\text { Regional } \\
\text { Substages }\end{array}$ & $\begin{array}{l}\text { Baritella } \\
\text { pavlovskajae }\end{array}$ & $\begin{array}{l}\text { Baritella } \\
\text { dmitrievae }\end{array}$ & $\begin{array}{l}\text { Baritella } \\
\text { tkatchevae }\end{array}$ \\
\hline Frasnian & $\begin{array}{l}\text { Pa. transi- } \\
\text { tans }\end{array}$ & Sargaev & & & \\
\hline Givetian & $\begin{array}{l}\text { M. falsi- } \\
\text { ovalis }\end{array}$ & ${ }_{\mathrm{L}}^{\text {Timan }}$ & & & \\
\hline
\end{tabular}

Fig. 2. Distribution of Baritella species in Devonian deposits of the Timan-Pechora province. Standard conodont zonation after Ziegler \& Sandberg (1990).

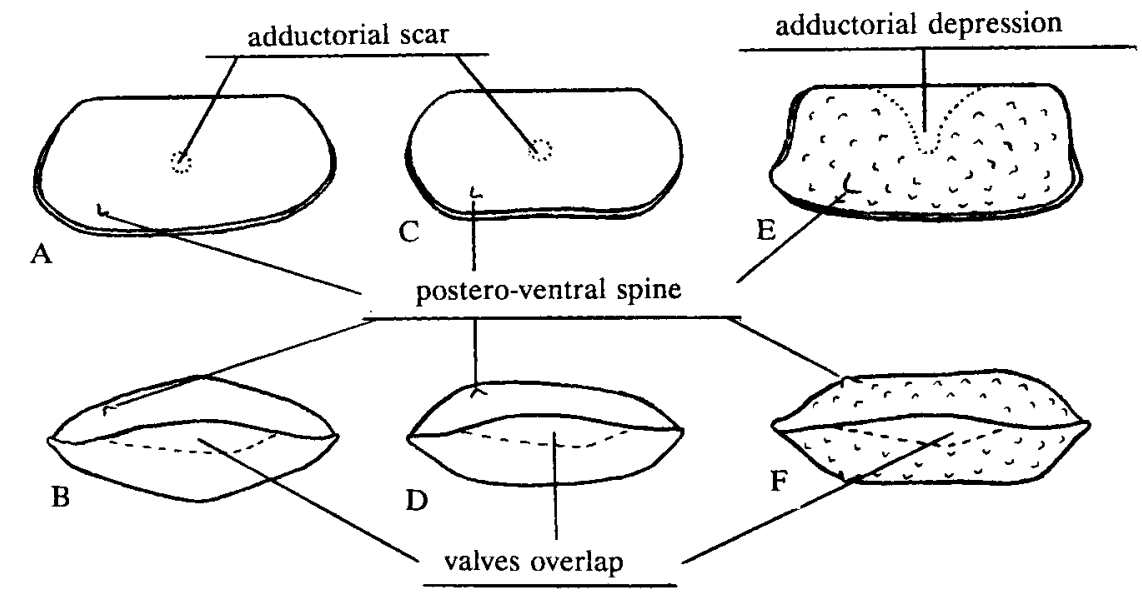

Fig. 3. (A, B) Baritella pavlouskajae sp. nov.; (C, D) Baritella dmitrievae sp. nov.; (E, F) Baritella tkatchevae sp. nov.: A, C, E right lateral view, with adductorial scar marked by dotted line in $\mathrm{A}$ and $\mathrm{C}, \mathrm{B}, \mathrm{D}, \mathrm{F}$ ventral view, margin of right valve marked by dotted line.

present or absent on the left valve. Left valve larger than right. Right valve overlapped by left on the ventral margin. Surface smooth or with small tubercules. Sexual dimorphism unknown.

Remarks. The new genus has some resemblance to Orthocypris Kummerov, 1953 and Rectella Neckaja, 1958. Baritella differs from Orthocypris in the postero-ventral spine. Rectella has a groove on the dorsal margin and the dorsal borders overreach the hinge line, while the new genus does not have a groove. Baritella includes the following species: Baritella tkatchevae sp. nov.; $B$. pavlouskajae sp. nov.; Baritella dmitrievae sp. nov.
Baritella tkatchevae sp. nov.

(Pl. 1, figs 1-5)

Derivation of name. After ostracodologist I.D. Tkatcheva. Diagnosis. Carapace of subtrapezoidal elongated lateral outline and subrectangular elongated dorsal outline. Carapace has an adductorial depression on the valves. Postero-ventral spine present on both valves. Lower part of postero-ventral and anterio-ventral margins are straight: and valve tapers posteriorly and anteriorly.

Holotype. VNIGRI, laboratory of microfauna, no. 5, collection 985.

Material. Seventeen carapaces.

\section{Explanation of Plate 1}

Figs 1-5. Baritella tkatchevae sp. nov.: holotype, VNIGRI, laboratory of microfauna, no. 5, coll. 985, Upper Devonian, Lower Frasnian, Sargaev regional substage (lower part). Russia, Timan-Pechora province, Sharju River, exposure 1, bed 18: fig. 1, car. right side, stereopair, $\times 80$; fig. 2, detail, postero-ventral spine, stereopair, $\times 300$; fig. 3, car. dors., stereopair, $\times 80$; fig. 4, car. vent, stereopair, $\times 80$; fig. 5, car. post., $\times 80$. Figs 6-8. Baritella dmitrievae sp. nov.: specimen, VNIGRI, laboratory of microfauna, no. 7, coll. 985, Upper Devonian, Lower Frasnian, Sargaev regional substage (lower part). Russia, Timan-Pechora province, Jarega River, exposure 16, bed 6: fig. 6, car. right side, stereopair, $\times 80$; fig. 7. car. dors., stereopair, $\times 80$; fig. 8 , detail, postero-ventral car. spine, $\times 510$. 


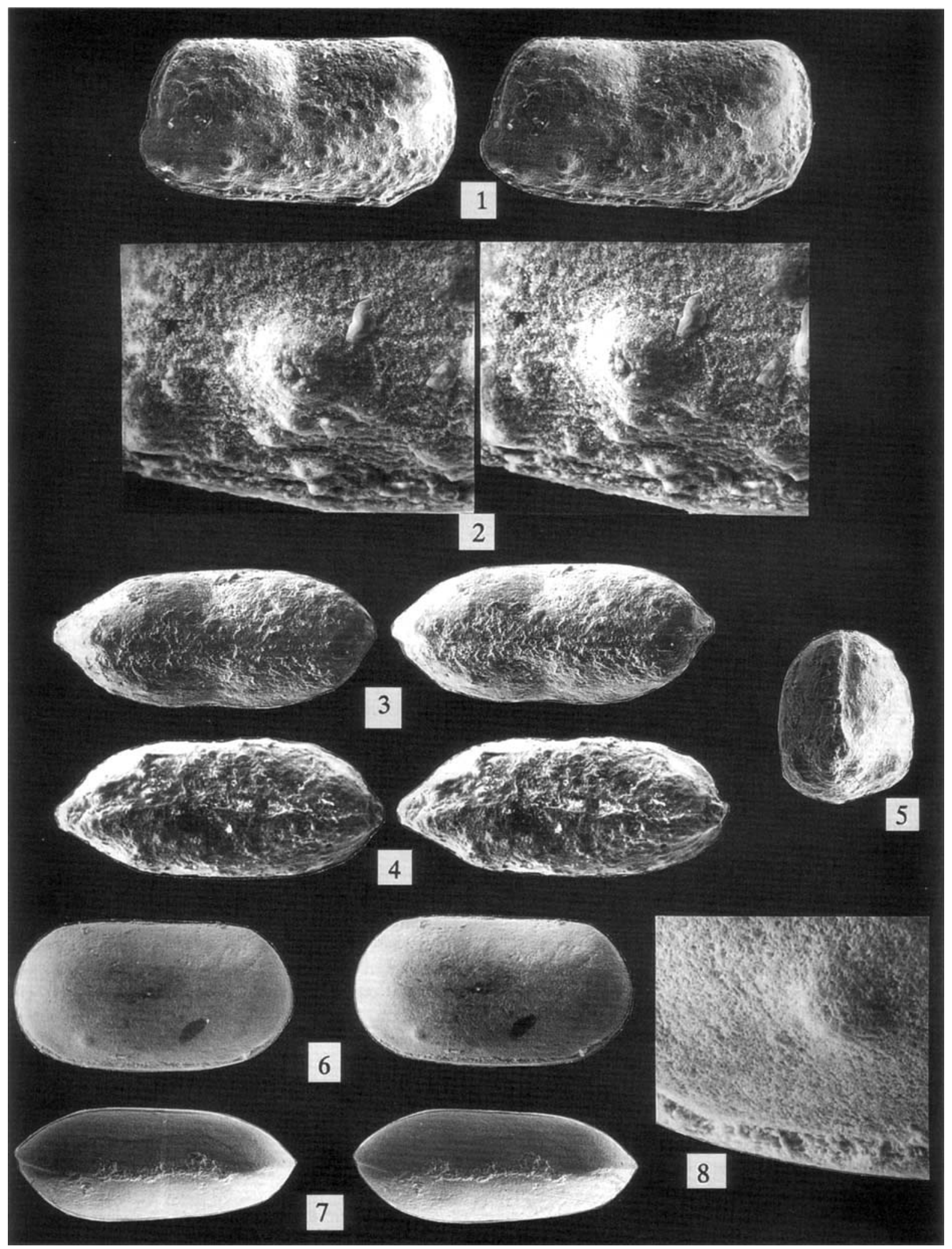

Plate 1 
Locality and horizon. Upper Devonian, Lower Frasnian, Sargaev regional substage (lower part). Russia, TimanPechora province, Sharju River, exposure 1, bed 18 (Orlov, 1990).

Description. Carapace subtrapezoidal, elongated in lateral outline and subrectangular elongated in dorsal outline. Anterior end is somewhat higher than posterior. Dorsal margin is straight and long. Ventral margin is slightly convex, straight in the middle part. Anterior margin is substraight. Upper part of anterior margin is somewhat thickened, lower part is slightly flattened and usually forward. Lower part of the posterior margin is slightly flattened and drawn back. Maximum length is in the lower part of the carapace, maximum height in the anterior part, maximum width in middle part. Adductorial depression is in the middle part of valves. It begins from the dorsal margin and extends to the middle part of the valve. The postero-ventral spine is situated on the postero-ventral part of each valve. The left valve is larger than the right. The right valve is overlapped by the left on the ventral margin. The surface has small tubercules. Moreover, under high magnification (more than $\times 100$ ) vague microornament is visible.

Dimensions of holotype. Length $0.70 \mathrm{~mm}$, height $0.35 \mathrm{~mm}$, width $0.28 \mathrm{~mm}$.

Remarks. This species differs from other Baritella species in having a poster-ventral spine on both valves, in the character of the lower parts of posterior and anterior margins, the adductorial depression and small tubercules on the surface.

\section{Baritella pavlouskajae sp. nov.} (Pl. 2, figs 6-9)

Derivation of name. After Ostracodologist V.I. Pavlovskaja.

Diagnosis. Carapace of subtrapezoidal lateral outline and rhomboidal dorsal outline. Posterior end usually higher than anterior. Postero-ventral spine on the right valve. Surface smooth.

Holotype. VNIGRI, laboratory of microfauna no. 4, collection 985.

Material. A few tens of carapaces from exposure 18. Locality and horizon. Middle Devonian, Upper Givetian, Timan regional substage (upper part). Russia, TimanPechora province, Ukhta River, exposure 18 (Judina \& Moskalenko, 1988).

Description. Carapace of subtrapezoidal lateral outline and rhomboidal dorsal outline. Posterior end usually somewhat higher than anterior. Dorsal margin straight and long. Ventral margin slightly convex. Anterior margin oval in outline with its apex situated below the middle of the carapace. Posterior end oval and somewhat tapered. Maximum length is in the lower part of the carapace, maximum height in the posterior or middle part, maximum width in the middle part. The postero-ventral spine is situated on the right valve. The left valve is larger than the right. The right valve is overlapped by the left on the ventral margin. Surface smooth.

Dimensions of holotype. Length $0.63 \mathrm{~mm}$, height $0.33 \mathrm{~mm}$, width $0.25 \mathrm{~mm}$.

Remarks. This species differs from Baritella dmitrievae sp. nov. in its subtrapezoidal lateral outline and rhomboidal dorsal outline, usually higher posterior end, and maximum length situated in the lower part of the carapace.

Baritella dmitrievae sp. nov.

(Pl. 1, figs 6-8; Pl. 2, figs 1-5)

Derivation of name. After micropalaeontologist T.V. Dmitrieva.

Diagnosis. Subrectangular elongated in lateral and dorsal outlines. Anterior and posterior ends equal. Posteroventral spine on the right valve. Surface smooth.

Holotype. VNIGRI, laboratory of microfauna no. 6 , collection 985.

Material. A few tens of carapaces from exposure 16 (Jarega River), and 15 carapaces from exposure 14 (Ukhta River).

Locality and horizon. Upper Devonian, Frasnian, Sargaev regional substage Jarega River, exposure 16, bed 6 (Judina \& Moskalenko, 1988).

Description. Carapace subrectangular, elongated in lateral and dorsal outlines. Anterior and posterior ends equal. Dorsal margin straight and long. Ventral margin slightly convex, straight in the middle part. Anterior and posterior margins rounded. Maximum length and height situated in the middle part of the carapace. Maximum width in the posterior or middle part. The postero-ventral spine is situated on the postero-ventral part of the right valve. The left valve is larger than the right. The right valve is overlapped by the left on the ventral margin. Surface smooth.

Dimensions of holotype. Length $0.65 \mathrm{~mm}$, height $0.35 \mathrm{~mm}$, width $0.25 \mathrm{~mm}$. Specimen no. 7. Length $0.65 \mathrm{~mm}$, height $0.35 \mathrm{~mm}$, width $0.27 \mathrm{~mm}$.

Remarks. This species differs from Baritella pavlovskajae sp. nov. in its subrectangular shape in lateral and dorsal outlines, equal height of anterior and posterior ends and maximum length situated in the middle part of the carapace.

\section{Manuscript received June 1994 Manuscript accepted May 1995}

\section{Explanation of Plate 2}

Figs 1-5. Baritella dmitrievae sp. nov.: holotype, VNIGRI, laboratory of microfauna, no. 6, coll. 985, Upper Devonian, Lower Frasnian, Sargaev regional substage (lower part). Russia, Timan-Pechora province, Jarcga River, exposure 16, bed 6: fig. 1, car. right side, stereopair $\times 80$; fig. 2, car. post., $\times 80$ : fig. 3, car. dors., stercopair, $\times 80$; fig. 4, car. vent, stereopair, $\times 80$; fig. 5, detail, postero-ventral car. spine, stereopair, $\times 510$. Figs 6-9. Baritella pavlovskajae sp. nov.: holotype, VNIGRI, laboratory of microfauna, no. 6, coll. 985, Middle Devonian. Upper Givetian, Timan regional substage (upper part). Russia, Timan-Pechora province, Ukhta River, exposure 18, example 21: fig. 6, car. right side, stereopair, $\times 80$; fig. 7, car. vent, stereopair, $\times 80$; fig. 8 , post., $\times 80$; fig. 9, car. dors., stercopair, $\times 80$. 


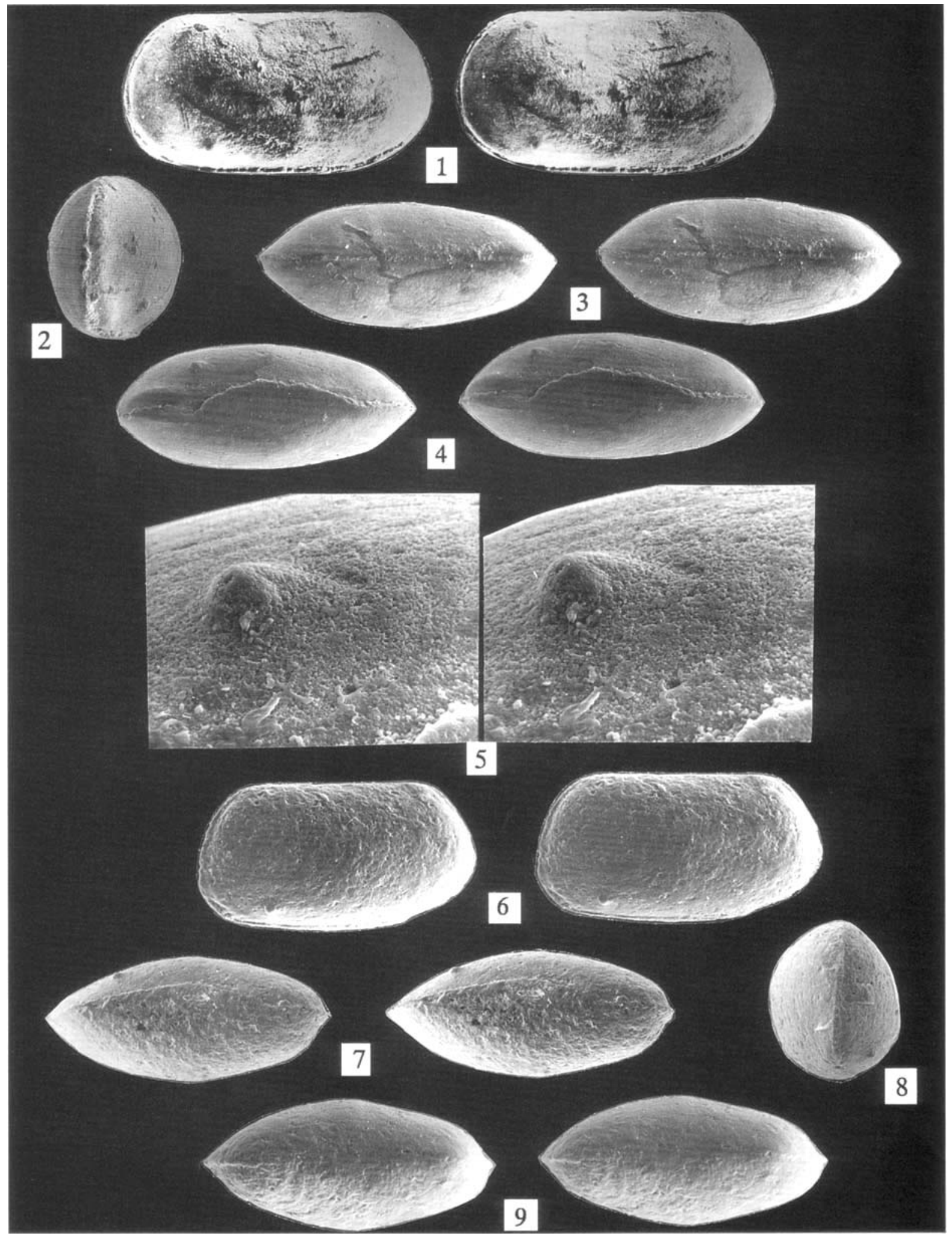

Plate 2 
REFERENCES

Judina, J. A. \& Moskalenko, M. N. 1988. Type section of Frasnian stage of South Timan. Timan-Pechora department of VNIGRI, Uchta: 1-52 [in Russian].

Orlov, A. N. 1990. Ostracod associations from Upper Devonian deposits of the Sharju River (North-East of Timan-Pechora province). Transactions of VNIGRI, Leningrad: 22-29 fin Russian].

Ziegler W. \& Sandberg, C. A. 1990. The late Devonian standard Conodont Zonation. Courier Forschungsinstitut Senckenberg, 121: $1-115$. 